DOI https://doi.org/10.32837/app.v0i66.712

УДК 32.019.51

\author{
М. М. Бурдюг \\ orcid.org/0000-0003-0017-3588 \\ аспірант каредри політичних наук \\ Київського національного університету імені Тараса Шевченка
}

\title{
ЧИННИКИ ЗРОСТАННЯ ПОПУЛІЗМУ В УМОВАХ ЛІБЕРАЛЬНОЇ ДЕМОКРАТІЇ
}

\begin{abstract}
Ліберальнадемократія -цемотоквовниздвома кіниями. Покиклубокперебуває у стані спокою, усе добре, але як тільки його починають розмотувати, нитки розділяються ще більще. Тягнути нитку лібералізму (свободи) - значить віддалятися від рівності. Тягнути нитку демократії (рівності) - означає досягати рівності, але при иъьому зменшувати ступінь свободи.
\end{abstract}

Джованні Сарторі

Постановка проблеми. Протягом останніх трьох десятиліть однією з центральних проблем політичної науки є дослідження феномену популізму в демократичних країнах. Всередині 1980-х рр. у європейських державах розпочалося зростання популістських сил, що породило у науковому співтоваристві дискусію про глибинні причини цього явища й фактори, які пояснюють відмінності в масштабах популярності популістських ідей у різних країнах.

На початку XXI ст. з'ясувалося, що глобалізація, зокрема ії локальне втілення - європейська інтеграція, має не тільки позитивні, але й негативні наслідки (Fryklund, 2013, p. 267). Протягом останніх 20 років збільшується приплив легальних і нелегальних іммігрантів, відбувається розмивання національної держави і суверенних прав урядів, розмивається грань між внутрішньою і зовнішньою політикою, спостерігаються численні негативні фактори: послаблення соціальних функцій держави, зростання безробіття, особливо серед молоді, нестабільність банківської системи тощо. Свою роль відіграють засоби масових комунікацій, які, оперезавши весь світовий інформаційний простір, стимулюють громадян до виявлення свого невдоволення таким станом речей. Ця ситуація поглиблюється низькою результативністю діяльності системних партій при владі.

За останні два десятиліття популістські партії досягли значних електоральних успіхів у Європі та перетворилися на нову політичну силу так званої «політичної альтернативи» - партії «Альтернатива для Німеччини» (Alternative für Deutschland), Австрійська партія свободи (Freiheitliche Partei Österreichs) і Швейцарська народна партія (Schweizerische Volkspartei). Посилення правих партій «політичної альтернативи» вписується у загальноєвропейський контекст. Вибори в Свропейський парламент показали, що в більшості країн Європи зміцнюються сили, які критично ставляться до поточного стану інтеграції, її перспектив, чинної політики влади у сфері міграції. В ідеологічному плані вони уособлюють рух за суверенітет, який протиставляє себе інтеграційному вектору та ультраліберальній системі цінностей європейських еліт. Тому вивчення тенденції зростання популізму в політичному просторі Європи стає більш актуальним.

Говорячи про популістські партії, слід підкреслити, що в цьому дослідженні під ними розуміються політичні сили, щодо формулювання точної дефініції яких нині в експертному середовищі немає одностайності. Як зауважив бельгійський дослідник К. Мудде, йдеться про політичні партії, які «усім відомі, хоча і невідомо, як точно їх називати». Йдеться про досить відомі та легковпізнавані партії, програми яких складаються 3 простих гасел, що актуалізують питання вирішення найбільш назрілих проблем сучасності. Проте складно достеменно відповісти: це кадрові партії чи масові? Отже, актуальність теми дослідження зумовлена необхідністю поглибленого аналізу особливостей соціально-політичного середовища та різних чинників, які впливають на помітне посилення популістських ідей у країнах Європи. 
Огляд актуальних досліджень із проблеми. Проблематика популізму стала предметом досліджень багатьох європейських теоретиків. У праці Ф. Хартлеба (Hartleb, 2011), а також у роботі О. Гедена (Geden, 2007) порушено важливі питання про складові елементи популізму і його риси, які відрізняють його від радикалізму й екстремізму. Ф. Хартлеб також провів аналіз політичної поведінки популістських партій під час передвиборчих кампаній і їхніх методів впливу на електорат (Hartleb, 2011). Ці самі проблеми детально розглянуто у працях Ф. Декера (Decker, 2000).

Сучасний теоретик В. Галстон здійснив спробу проаналізувати причини виникнення популізму крізь призму відокремлення ліберальних та демократичних ідей і оптимального варіанту їхнього співвідношення в актуальному розумінні громадськості та політичних акторів глобального світу (Galston, 2017; 2018). Тему перспектив розвитку популізму у світі розкрито у працях Т. Пепес (Pappas, 2019).

3 другої половини XX ст. популізм поступово стає самостійним об'єктом наукових досліджень. Серед українських вчених аналіз чинників розвитку популізму був цікавим для О. Новакової, В. Бурдяк, І. Кіянки, Ю. Макара та інших. Проте в контексті політико-інституційних засад ліберальної демократії дослідження тенденцій зростання популізму та особливості феноменології цього поняття ще не були предметом системного аналізу.

Мета статті (завдання дослідження) - проаналізувати феномен зростання популізму в ліберальних демократіях, розглянути його як особливу конструкцію «неліберальної демократії», дослідити чинники зростання популізму в європейських країнах.

Виклад основного матеріалу. Ліберальна демократія в сучасній політичній науці детермінується певним ідеалом, на основі якого будуються усі класифікації політичних режимів. Ліберальна демократія - це форма демократичного правління, в якій знайдено рівновагу між принципом обмеженого управління і принципом участі громадян (народу) у політиці. Термін «ліберальна демократія» ілюструє певну політичну філософію, також вживається для вираження певного політичного режиму (Mesežnikov, 2008, p. 24).

Ліберальній демократії як політичному режиму властиві:

- конституційна система державного управління;

- розподіл влади, механізми стримування і противаги владі;

- регулярні вибори;

- політичний плюралізм, змагальна політична конкуренція за демократичними правилами політичної гри;

- наявність у суспільстві незалежних груп інтересів;

- ринкова приватновласницька економіка.

Умовно можемо виділити два змістовні компоненти ліберальної демократії:

- ліберальний зміст: наявність системи зовнішніх і внутрішніх стримувань влади, покликаних гарантувати свободу особистості й забезпечити захист громадян від надмірного державного вручання;

- демократичний зміст: наявність системи регулярних і змагальних виборів, яка проводяться на основі всезагального виборчого права й політичної рівності.

У наукових працях різних історичних періодів (від Алексіса де Токвіля до Раймона Арона) проблема поєднання демократії і лібералізму демонструє специфічні відносини між свободою і рівністю (табл. 1). Як тільки виникає спроба суттєво посилити і одне, й інше, виникає криза. На думку В. Галстона, важливим чинником сучасності стає внутрішній виклик ліберальній демократії - виклик популістів, які прагнуть роз'єднати демократію та лібералізм (Galston, 2018). Вони стверджують, що ліберальні норми та політика (цінності лібералізму) послаблюють демократію і шкодять людям.

Популістські сили позиціонують себе як альтернативу не конкретній політичній партії, а як альтернативу наявній представницькій системі загалом. Лідери таких сил обіцяють пожвавити політичне життя й повернути назад «сенс» для політики. Водночас феномен популізму важко осмислити частково тому, що він надзвичайно залежить від контексту (візьмімо, наприклад, різницю між Венесуелою й Росією). Проте, без сумніву, спільною рисою є те, що популісти завжди звертаються до «народу загалом» (як єдиного джерела суверенної влади), а не до «корумпованих» та «імпотентних» політичних еліт. 
Дихотомія змістовного наповнення сутності ліберальної демократії

\begin{tabular}{|c|c|}
\hline Лібералізм & Демократія \\
\hline Свобода & Рівність \\
\hline Гетерогенність і спонтанність & Соціальна цілісність \\
\hline $\begin{array}{c}\text { Самовпевненість і недисциплінованість, } \\
\text { які породжуються свободою }\end{array}$ & $\begin{array}{c}\text { Незначне відчуття плюралізму (суперечність } \\
\text { між ідеєю повновладдя народу й неможливістю } \\
\text { Пї практичного втілення) }\end{array}$ \\
\hline
\end{tabular}

Популістські сили виступають проти ключової ідеї ліберальної демократії, а саме політична більшість повинна бути обмежена важливими конституційними обмеженнями. Ілюзія (а не інтереси прав меншин) постають кінщевою основою легітимації в політиці. Популісти кидають виклик багатьом елементам «ліберального консенсусу»- ринково орієнтованим реформам, євроатлантичній інтеграції і «дають змогу» громадянам долучитися до їх відвертої критики.

Нині популізм - це поняття, яким дослідники, експерти, громадськість позначають велику кількість різних явищ і процесів (Dukanovic, 2014). Великий інтерес до популізму охопив головну політичну тенденцію глобального світу - наростання демократичного нелібералізму. У публічному дискурсі консолідованих демократій характеристика політичного актора як популіста досить часто може вважатися негативною оцінкою. Популярною у науковому середовищі $є$ точка зору, що феномен популізму виник не з підйому антидемократичних та авторитарних альтернатив, а через неперервне масштабування демократії. Це в контексті низки країн поряд із величними намірами подалышої розбудови системи гарантій прав людини третього і четвертого поколінь не знаходить достатнього економічного підтвердження.

Наукова література дає підстави говорити про плюралізм думок у формулюванні дефініції категорії «популізм». Одні вчені інтерпретують його як стиль політичної комунікації, інші - як підкріплену фактами й діяльністю риторику, окремі дослідники визначають його як електоральну стратегі в питанні мобілізації мас. $€$ точка зору щодо ототожнення популізму й демократії. Такий широкий спектр думок засвідчує багатогранність розуміння цього явища.

Популізм - це кліпова, фрагментована ідеологія, яка поділяє суспільство на дві антагоністичні спільноти - «благородний народ» і «корумповану еліту». Причому політика повинна бути абсолютним виявленням загальної «волі народу» і діяти в інтересах народу. Популізм не є викликом для демократії, що засновується на ідеях вільних виборів і правилі більшості. На відміну від екстремальних партій 1930-х рр. (фашисти, комуністи), нові популісти не мають на меті обмежувати інститут виборів чи запроваджувати диктатуру. Популістські партії, як i інші, відповідно до логіки функціювання партії запрограмовані боротися за державну владу і для цього активно беруть участь у виборах, але вони категорично проти будь-яких обмежень суверенітету людей.

Коли ми обговорюємо підйом популізму нині, то маємо на увазі процес розмивання ліберального консенсусу, який виник після закінчення холодної війни; маємо на увазі зростання напруженості між принципами демократичної більшості та ліберального конституціоналізму як двома основними елементами ліберально-демократичних режимів (табл. 1). Прихильники ліберальних ідеологій стривожені цими останніми подіями (Johansson, 2014). Частина проблеми полягає у тому, що вони не поділяють поширені тлумачення природи, глибини та характеру сучасних соціально-політичних криз. Ситуація втоми й розчарування швидкістю ринкових реформ, велика кількість проблем, пов' язаних з інтеграційними процесами всередині Європи, не додають оптимізму через ліберальний консенсус.

Динаміка популістських тенденцій в країнах Заходу у XXI ст. стала серйозним симптомом глибинних соціокультурних, економічних і політичних трансформацій суспільства, причиною яких були інформаційно-технологічна революція, глобалізація та демографічні зміни. Взаємозумовленими названими модернізаційними тенденціями в західних демократіях стали страхи перед імміграцією, економічною стагнацією, колапсом «держави загального добробуту».

Сучасний популізм - продукт ліберальної демократії, і популістські лідери, завойовуючи владу, починають пристосовувати свою політику під демократичні інститути. Однак він несе 
в собі і серйозну загрозу для Заходу. Ретроспективний аналіз дає підстави стверджувати, що в умовах соціально-економічної нестабільності громадяни (особливо носії буденної політичної свідомості) з легкістю підпадають під спокусливу риторику популістів і дотримуються їхніх ідеологічних доктрин (Mesežnikov, 2008; Mudde, 2000).

Подібні процеси мали негативні наслідки для усього світу. Майбутній внутрішньополітичний дизайн Свропи й Північної Америки багато в чому залежить від результату поточного поєдинку. «Чи зможе ліберальна демократія швидко й ефективно адаптуватися до популістських викликів, чи популізм стане альтернативою демократії, розмиваючи їі ідейно-політичну та інституційну архітектуру?» - нині це відкрите питання.

Ліберальна демократія базується на ідеї політичної рівності, тоді як в основі популізму лежать антиплюралізм, антидемократичність, конфронтаційність. Політичні кейси політики з сучасних Австрії, Великобританії, Угорщини, Німеччини, Італії, Франції, США певною мірою підтверджують таку загальну характеристику. При цьому ключовим моментом для сучасного варіанту популізму можна вважати те, що по суті він є продуктом ліберальної демократії, яка базується на інститутах представництва та підзвітності, цінностях плюралізму і свободи, правах людини й верховенстві закону. У цьому плані зростання популістських партій і рухів останнім часом стало перевіркою на міцність для західних ідейних, політичних та інституційних систем.

Розглядаючи популізм в ідеологічному фокусі, можна виявити його властивості як фрагментованої ідеології, яка не є самостійною, а використовує концепти основних ідеологій формування власного дискурсу. Популізм може формулювати свій порядок денний, вдаючись і до лівих (соціал-демократичних / ліберальних) ідей, і до правих (консервативних). Звідси від кейсу до кейсу окремі політичні сили чи не в кожній державі світу отримують право або ліво-популістську характеристику. Основна ідеологія як самостійна система ідей, узагальнена на політико-філософському рівні, є в цьому випадку своєрідним «донором».

Протягом чотирьох десятиліть після закінчення Другої світової війни успіхи популістських сил у західноєвропейських державах здебільшого носили локальний характер. Однак у середині 1980-х рр. у Західній Європі окреслилася тенденція до зростання популярності популістських партій, яка зберігається й нині. Умовною точкою відліку для цього процесу прийнято вважати 1984 рік, коли у Франції за підсумками виборів до Європейського парламенту переміг Національний фронт. Протягом подальших трьох десятиліть популістські партії значно зміцнили своє становище в партійно-політичних системах європейських країн. Нині популістські партії представлені в національних парламентах переважної більшості держав Західної Європи, зокрема в Австрії, Бельгії, Великобританії, Греції, Данії, Італії, Нідерландах, Норвегії, Фінляндії, Франції, Швеції, Швейцарії. Із західноєвропейських країн лише в Іспанії, Ірландії, Люксембурзі та Португалії популярність популістських партій перебуває не на високому рівні (так звані failed cases) (Rydgren, 2005, p. 415).

Варто наголосити, що в різних країнах внутрішньополітичне становище популістських партій має свої особливості. Наприклад, в Австрії, Італії, Нідерландах, Норвегії та Швейцарії ці партії мають досвід роботи у структурах виконавчої влади на національному та/або регіональному рівнях. Це помітно контрастує з ситуацією, яка спостерігалася у цих країнах в 19801990-х рр., коли взаємодія з популістами цілком відкидалася політичним істеблішментом.

Партія є одним із найбільш важливих інструментів політичного вияву (Шайгородський, 2002). Через свою сильну організаційну спрямованість щодо участі в політичному житті партія постає дієвим виразником потреб і цілей певних соціальних груп, вносить свою рушійну силу до сфери управління та детермінує напрям, у якому будуть діяти органи державної влади. Новим чинником розвитку політичної партії, який зумовив деяку потребу трансформувати механізми діяльності традиційної партії відповідно до викликів XXI століття, стала ідеологічна дерадикалізація.

Зміна панівної системи цінностей (від матеріальних до постматеріальних за концепцією «мовчазної революції» Рональда Інглхарта (праця «Тиха революція», 1977 р.) викликала потребу оновити зміст ідеологічної основи діяльності партії - 3 програми партій починають вимиватися окремі елементи, які ідентифікують ії соціальну базу та стабільний електорат. Іде 
в історію модель традиційної партії, побудована на масовому членстві, репрезентації соціальних інтересів, досить жорсткій організаційній структурі й ідеологічній ідентифікації.

На зміну таким приходять «всеохопні» партії (catch-all parties), для яких характерні розмиті ідеологічні структури, усе більш туманні програмні обіцянки, елітарне панування в партійному житті, що демобілізує рядових членів. Логіка діяльності таких партій зводиться до пошуку голосів виборців де завгодно. Звужується коло осіб, які здійснюють реальний вплив на політику, громадяни рідко безпосередньо включені в політичний процес і голосують випадковим чином. Виборцям пропонується зробити вибір між всеохопними політичними програмами, які найчастіше розпливчасті, переплутані та популістські. Це зумовлює бідний результат щодо якості політики та демократії.

Сучасна політична наука, досліджуючи еволюцію моделей політичної партії, фіксує у них зниження ідеологічного чинника та підвищення технологічного складника. Взагалі політичний процес у XXI ст. характеризується значною технологізацію, підвищенням ролі політичного лідерства й поширенням популістських гасел. Кейс України цікавий тим, що, вийшовши 3 тоталітарної однопартійності, ця держава потрапила в гіпертрофовану багатопартійність. На сучасному етапі розвитку України спостерігаються і намагання до консолідації наявних партійно-політичних сил з метою створення дієздатної партійної системи, і деструктивні процеси, властиві для перехідних суспільств.

Сучасні політичні партії в Україні так і не змогли виконати функцію дієвого посередника у відносинах між особою та державою, адже політичні партії 90-х і 2000-х рр. утворилися раніше, ніж склалися соціальні групи населення, інтереси яких ці партії покликані відображати. Майже усі партії в сучасній Україні апелюють до середнього класу, хоча, за різними підрахунками, він становить лише від 15 до 25\% у соціальній структурі українського суспільства. Іще одним важливим аспектом дослідження стала соціально-культурна специфіка українського суспільства й регіональні особливості України - основні рамки та маркери риторики політичних партій, які часто з технологічною метою набували характеристик популізму та політичних міфів.

Суттєвою ознакою мажоритарних партій є їхня реалістична програма, адже вона може бути випробувана політичним життям. Будь-яка демагогія та популізм з боку мажоритарної партії ризикують обернутися проти неї, тому така партія завжди повинна обіцяти лише те, що може виконати, і ставити акцент на конкретних суспільних проблемах. Останнім часом в Україні набувають популярності так звані віртуальні партії, видимість існування яких створюється і підтримується 3МІ. Відірваність від суспільних верств, превалювання інтересів партійних еліт над інтересами виборців зумовлюють кон'юнктурну політичну поведінку партій і низький рівень довіри до них населення (Дюверже, 2000).

Західноєвропейські популістські партії багаторазово ставали об'єктом різних наукових досліджень у другій половині XX - на початку XXI століття. При цьому інтерес до цієї теми в науковому середовищі неухильно зростав із тим, як ці політичні сили завойовували прихильність виборців на виборах, збільшуючи і своє представництво в органах влади, і ступінь впливу на політичні процеси загалом.

Слід зазначити, що до другої половини 1980-х рр. популістські партії (як ми розуміємо їx у цьому дослідженні) найчастіше, не підпадаючи під традиційні класифікації, ототожнювалися багатьма дослідниками 3 неонацизмом і неофашизмом. Найважливіше значення в дослідження цієї проблеми вніс К. фон Бейме, який у своїй роботі 1988 року, виділивши три хвилі в розвитку правого радикалізму у Західній Європі, провів чітку межу між маргінальними неонацистськими організаціями, які виникли в Європі у 1950-60-ті рр. (перша хвиля), так званими партіями прогресу, які досягли обмежених успіхів у 1970-х рр. в країнах Скандинавії (друга хвиля), і власне популістськими рухами, які вийшли на політичну арену в 1980-х рр. (третя хвиля) (Fryklund, 2013). Теорія К. фон Бейме стала визначальною для цілого напряму наукових досліджень, присвячених різним аспектам сучасного політичного популізму.

Робота К. фон Бейме насамперед дала відчутний імпульс дослідженню питань, пов' язаних із глибинними причинами, що зумовили не тільки безпосередньо появу популістських партій на політичній арені, а й їхні електоральні успіхи. У таких роботах автори шукають відповіді на такі питання: «хто й чому голосує за популістські партії», «чому в одних країнах попу- 
лісти є популярнішими, ніж в інших», «які інституційні, демографічні, соціальні, економічні та інші чинники підвищують імовірність голосування за популістів», «чи впливає імміграція на зростання популярності популістських партій».

Імовірно, що серед виборців завжди існують групи, найбільш вразливі до впливу популістської пропаганди («жертви модернізації»). Водночас для того, щоб такий вплив був відчутним, для результату голосування за популістську партію на виборах у соціальній, економічній, демографічній і культурній сферах суспільного життя мають з'явитися певні передумови. Х.-Г. Бетц виділяв і роль такої передумови як зростання кількості іммігрантів у країнах Західної Європи в другій половині XX століття (Dukanovic, 2014).

Основна складність, пов'язана з пошуком найбільш точного визначення популістських партій, полягає у тому, що (на відміну від абсолютної більшості політичних сил у розвинених демократичних системах) вони не належать до традиційних партійних сімей. 3 погляду ідеології вони поєднують дискурс, властивий і правим, і лівим партіям. Тому їхній порядок денний може мати різне наповнення, однак здебілышого він зводиться до актуалізації питань, «замовчуваних» політичним істеблішментом: захист національної ідентичності корінного населення, захист традиційних сімейних цінностей, максимальне обмеження імміграції, вжиття рішучих заходів, спрямованих на боротьбу зі злочинністю, украй негативне ставлення до Євросоюзу, пов' язане з нереалізованими очікуваннями пересічних громадян щодо зростання їхнього економічного добробуту, різка критика інститутів $Є С$, яка з цього випливає.

Що стосується терміну «антисистемні партії», то й він здається не дуже вдалим, оскільки більшість охоплених ним партій не ставить перед собою за мету знищення чинної демократичної політичної системи. Для визначення «усім відомих партій» кращим є термін «популістські партії», оскільки він багато в чому дозволяє уникнути проблем, пов'язаних із зазначеними вище іншими визначеннями, а також найбільш цілісно відображає досліджуваний феномен. Цей термін, вказує на відсутність у таких сил чіткого позиціонування на «праволівій» шкалі і не акцентує увагу на якомусь окремому аспекті їхньої ідеології (Taggart, 2000). В цьому контексті визначення «популістський» не несе в собі оціночної характеристики.

Висновки та перспективи подальших досліджень. Одним із основних чинників зростання популізму є недостатня результативність інститутів опосередкованої демократії в сучасних консолідованих демократіях. На практиці ідеалізація технократичного підходу, за якого ухвалення рішень виявилося здебільшого делегованим «освіченій» бюрократії, яка не виявила належного ступеню відповідальності ідеї забезпечення суспільного інтересу у своїй діяльності, що спровокувало скептичне ставлення мас до інституційної «архітектури» ліберальної демократії.

Інша причина зростання популізму пов' язана з тенденцією ідеологічної дерадикалізації, яка виявилася в діяльності всеохопних партій. Партійно-політична система є інституціональним каркасом ліберальної демократії, яка забезпечує реалізацію народного суверенітету та інтересів різних соціальних прошарків. Вона $є$ виявленням ідеї політичного різноманіття та широкого представництва й одночасно символом єдності. Однак саме деградація партій у розвинених західних демократіях, яка спостерігається протягом останніх десятиліть, стала вразливим місцем ліберальної демократії у ії протистоянні $з$ популізмом.

Партійним структурам не вдалося адаптувати політичну систему згідно 3 динамікою зовнішнього довкілля й зростаючими запитами громадян, а також запропонувати громадськості адекватні альтернативи суспільного розвитку. Найпростішим шляхом стало звернення до популістських гасел, які, ілюзорно окреслюючи реалістичність легких шляхів вирішення складних проблем, дозволяли швидко та з мінімальними витратами мобілізувати виборців. Загалом сучасний популізм - це продукт ліберальної демократії, для якого (не)реалістичні інститути (прямої) демократії мають велике значення. 3 іншого боку, у рамках консолідованої демократії популізм несе у собі потужне антидемократичне спрямування.

Нині ліберальна демократія має виявити усю свою інституційну спроможність, гнучко зреагувати на сучасні виклики глобального світу й не допустити розмивання своєї ідейно-політичної структури через популізм. Досить перспективним буде подальше вивчення феномену популізму на прикладі кейс-стаді країн Центрально-Східної Європи. 


\section{Лiтература}

Шайгородський Ю. Виборче законодавство України. Київ : Український центр політичного менеджменту, 2002. 296 с.

Дюверже М. Политические партии. Москва : Академический Проект, 2000. 538 с.

Decker F. Parties under pressure. The new right-wing populism in Western democracies. Opladen : Leske und Budrich Verlag, 2000. 214 p.

Decker F. Populism. Danger to democracy or useful corrective? Wiesbaden : Springer VS, 2006. URL: https:/ /doi.org/10.1007/978-3-531-90163-3_1.

Dukanovic D. Populist parties in selected European countries. Turku : University of Turku Centre for Parliamentary Studies, 2014. URL: https://silo.tips/download/populist-parties-in-selected-europeancountries.

Fryklund B. Populism - changes over time and space. A comparative and retrospective analysis of populist parties in the nordic countries from 1965 to 2012. Right-wing populism in Europe: politics and discourse / ed. by R. Wodak, M. Khosravinik, B. Mral. London : Bloomsbury Academic, 2013. P. 267-276.

Galston W. The 2016 U.S. election: the populist moment. Journal of Democracy. 2017. № 28. P. $23-46$.

Galston W. The populist challenge to liberal democracy. Journal of Democracy. № 29(2). P. 2018. 5-19.

Geden O. Right-wing populism. Function logics, opportunity structures-counter-strategies. Berlin : Stiftung Wissenschaft und Politik, 2007. 246 p.

Goodhart D. The road to somewhere: the populist revolt and the future of politics. London : Hurst, 2017.256 p. Hartleb F. After its establishment. Right-wing populist parties in Europe. Berlin : Konrad-Adenauer-Stiftung, 2011. 368 p.

Johansson K. How populist parties organize: PESO research report. Södertörn : School of Social Sciences Södertörn University, 2014. № 2. URL: https://www.researchgate.net/publication/326941469_How_ Populist_Parties_Organize.

Kornhauser W. The Politics of Mass Society. London : Routledge, 2010. 272 p.

Mesežnikov G. Populism and liberal democracy in Central and Eastern Europe. Bratislava : Institute for public affairs, 2008. 132 p.

Mudde C. The populist "zeitgeist". Government and Opposition. 2000. № 39. P. 48-68.

Mudde C. The war of words. Defining the extreme right party family. West European Politics. 1996. № 19. P. 233-264.

Pappas T. Populism and liberal democracy: comparative and theoretical analysis. Oxford : Oxford University Press, 2019. 336 p.

Rydgren J. Is extreme right-wing populism contagious? Explaining the emergence of a new party family. European Journal of Political Research. 2005. № 44(3). P. 414-456.

Taggart P.A. Populism. Buckingham : Open University Press, 2000. URL: https://doi.org/10.1080/13569310 42000263528.

\section{References}

Shajgorodskyj Yu. (2002). Vyborche zakonodavstvo Ukrayiny [Electoral legislation in Ukraine]. Kyiv : Ukrayinskyj centr politychnogo menedzhmentu [in Uktainian].

Dyuverzhe M. (2000). Polytycheskye partyy [Political Parties]. Moskow : Akademycheskyj Proekt [in Russian].

Decker F. (2000). Parties under pressure. The new right-wing populism in Western democracies. Opladen : Leske und Budrich Verlag.

Decker F. (2006). Populism. Danger to democracy or useful corrective? Wiesbaden : Springer VS.

Dukanovic D. (2014). Populist Parties in Selected European Countries. Retrieved from: https://silo.tips/ download/populist-parties-in-selected-european-countries.

Fryklund B. (2013). Populism - Changes over time and space. A comparative and retrospective analysis of populist parties in the nordic countries from 1965 to 2012, in R. Wodak, M. Khosravinik, B. Mral (Eds.) Rightwing populism in Europe: Politics and discourse. London: Bloomsbury Academic, p. 267-276.

Galston W. (2017). The 2016 U.S. election: The populist moment. Journal of Democracy, $28,23$.

Galston W. (2018). The populist challenge to liberal democracy. Journal of Democracy, 29 (2), 5-19.

Geden O. (2007). Right-wing populism. Function logics, opportunity structures - counter-strategies. Berlin : Stiftung Wissenschaft und Politik.

Goodhart D. (2017). The road to somewhere: The populist revolt and the future of politics. London : Hurst.

Hartleb F. (2011). After its establishment. Right-wing populist parties in Europe. Berlin : Konrad-Adenauer-Stiftung. Johansson K. (2018). How Populist Parties Organize. Retrieved from: https://www.researchgate.net/ publication/326941469_How_Populist_Parties_Organize. 
Kornhauser W. (2010). The politics of mass society. London : Routledge.

Mesežnikov G. (2008). Populism and liberal democracy in Central and Eastern Europe. Bratislava : Institute for Public Affairs.

Mudde C. (2000). The populist "zeitgeist". Government and Opposition, 39.

Mudde C. (1996). The war of words. Defining the extreme right party family. West European Politics, 19.

Pappas T. (2019). Populism and liberal democracy: Comparative and Theoretical Analysis. Oxford : Oxford University Press.

Rydgren J. (2005). Is extreme right-wing populism contagious? Explaining the emergence of a new party family. European Journal of Political Research, 44 (3).

Taggart P. (2000). Populism. Buckingham : Open University Press.

\section{Анотація}

Бурдюг М. М. Чинники зростання популізму в умовах ліберальної демократії. - Стаття.

Проаналізовано сучасний популізм як виклик ліберальній демократії. Основним чинником зростання популізму визначено зниження привабливості ліберальних рішень у сферах політики, економіки та культури, наростання настроїв «відмови» від емпіричної політичної свідомості, зростання популярності політики заперечення.

Визначено характерні ознаки популізму як неінтелектуального, примітивного характеру, але дуже дієвого методу впливу на політичну аудиторію. Популізм є вагомим методом боротьби за владу в умовах нестабільного розвитку. Узагальнено, що популізм з'явився наприкінці XIX століття як громадський рух, ідеологія і вид політичної діяльності, який з того часу міцно зайняв свої позиції в політичній свідомості мас, набуваючи нових рис і активізуючись у періоди, коли країни переживали переломні етапи своєї історії.

Динаміку розвитку популізму як суспільно-політичного феномену в Україні проаналізовано на прикладі зростання популярності всеохопних партій (catch-all parties) і тенденцій ідеологічної дерадикалізації (індоктринації) політики загалом. На прикладі низки європейських партій досліджено феномени популізму та євроскептицизму як дві різні сторони одного протестного руху, що становить так звану «політичну альтернативу».

Як політологічна конструкція популізм ще не має достатнього теоретичного обгрунтування, проте має цілісну структуру. Наголошено, що популізм є загрозою не для демократії, а для провідного ліберального варіанту демократії. Завдання популізму - перетворити народні уподобання на державну політику без перешкод, які заважали ліберальним демократіям ефективно реагувати на нагальні проблеми (неліберальна демократія). Важливим чинником зростання популізму визначено недостатню дієвість конституціоналізму та інших формальних, обмежених інститутів, процедур для забезпечення принципів народного суверенітету, демократії, справедливості, забезпечення інтересів більшості в сучасному світі.

Ключові слова: ліберальна демократія, популізм, популістські партії, всеохопні партії, лібералізм, євроскептицизм.

\section{Summary}

Burdiuh M. M. Factors of populism growth in a liberal democracy. - Article.

Modern populism as a challenge to liberal democracy is analysed. The main factor in the rise of populism is the decline in the attractiveness of liberal decisions in the fields of politics, economics and culture, and the growing mood of "abandonment" of empirical political consciousness, the growing popularity of the policy of denial.

The characteristic features of populism as an unintellectual, primitive, but a very effective method of influencing the political audience are identified. Populism is a very effective method of fighting for power in the context of unstable development. It is generalized that populism appeared at the end of the $21^{\text {st }}$ century as a social movement, ideology and type of political activity. Since then, it has firmly taken its place in the political consciousness of the masses, acquiring new features and intensifying in periods when countries experienced turning points in their history.

The dynamics of populism as a socio-political phenomenon in Ukraine is analysed on the example of the growing popularity of catch-all parties and the trend of ideological deradicalization (indoctrination) of politics in general. On the example of a number of European parties, the phenomena of populism and Euroscepticism are studied as two different sides of one protest movement, which is the so-called "political alternative". As a political science structure, populism lacks a sufficient theoretical background, but, nevertheless, has a holistic structure. 
It is emphasized that populism is not a threat to democracy, but to the dominant liberal version of democracy. The objective of populism is to turn popular preferences into public policy without obstacles that prevented liberal democracies from responding effectively to pressing problems (illiberal democracy). An important factor in the growth of populism is the lack of effectiveness of constitutionalism and other formal, limited institutions, procedures to ensure the principles of people's sovereignty, democracy, justice, ensuring the interests of the majority in the modern world.

Key words: liberal democracy, populism, populist parties, catch-all parties, liberalism, euroscepticism. 